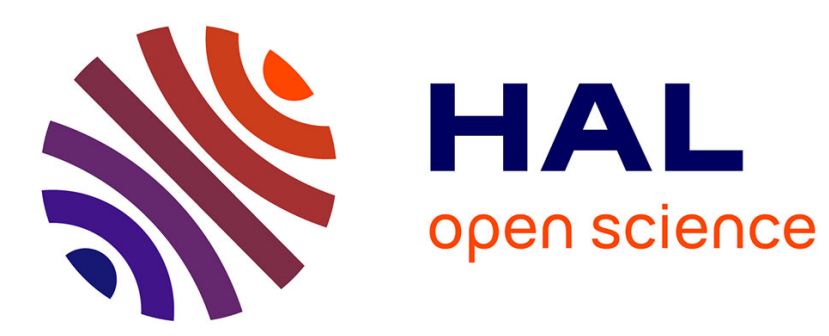

\title{
Nonlinear dynamics of a multimode lasers. From intracavity spectroscopy to femtoseconds
}

A. Kachanov

\section{To cite this version:}

A. Kachanov. Nonlinear dynamics of a multimode lasers. From intracavity spectroscopy to femtoseconds. Journal de Physique IV Proceedings, 1994, 04 (C4), pp.C4-720-C4-720. 10.1051/jp4:19944198 . jpa-00252659

\section{HAL Id: jpa-00252659 https://hal.science/jpa-00252659}

Submitted on 1 Jan 1994

HAL is a multi-disciplinary open access archive for the deposit and dissemination of scientific research documents, whether they are published or not. The documents may come from teaching and research institutions in France or abroad, or from public or private research centers.
L'archive ouverte pluridisciplinaire HAL, est destinée au dépôt et à la diffusion de documents scientifiques de niveau recherche, publiés ou non, émanant des établissements d'enseignement et de recherche français ou étrangers, des laboratoires publics ou privés. 


\title{
Nonlinear dynamics of a multimode lasers. From intracavity spectroscopy to femtoseconds
}

\author{
A.A. KACHANOV \\ Institute for Spectroscopy of the Russian Academy of Sciences \\ and Laboratoire de Spectrométrie Physique, Université Joseph Fourier Grenoble I, France
}

The influence of a nonlinear mode coupling on the time evolution of generation spectrum of a broadband multimode lasers will be described. The results are applied to the creation of laser spectrometers capable of measuring wery weak absorption spectra with quantum noise limited detection threshold. The prospects of using new solid-state laser mediae for the intracavity spectroscopy will be discussed.

A brief review of femtosecond systems for the study of transition states in chemical reactions will be done. (Ring CPM dye laser and self-mode-locked Ti:Sapphirebased laser/amplifier systems). Recent results with $\mathrm{Cr}^{4+}$ :YAG infrared mode-locked laser tunable in the range from 1.35 to $1.6 \mu$ will be described. 